\title{
Does Customer-Based Reputation Lead Customers Not to Switch? Examining Moderating Influences in Hypermarkets
}

\author{
Hao-Te $\mathrm{Lu}^{1} \&$ Yi-Chou Wang ${ }^{2}$ \\ ${ }^{1}$ Department of Business Administration, Tainan University of Technology, Tainan, Taiwan \\ ${ }^{2}$ Yi-Chou Wang, Department of International Business Management, Tainan University of Technology, Tainan, \\ Taiwan \\ Correspondence: Yi-Chou Wang, Department of International Business Management, Tainan University of \\ Technology, Tainan, Taiwan. E-mail: t90063@mail.tut.edu.tw
}

$\begin{array}{lc}\text { Received: April 15, } 2019 & \text { Accepted: May 8,2019 Online Published: May 21, } 2019 \\ \text { doi:10.5539/ijms.v11n2p64 } & \text { URL: https://doi.org/10.5539/ijms.v11n2p64 }\end{array}$

\begin{abstract}
Accumulating evidence underscores the importance of business reputation. Therefore, understanding the impact of reputation on customers is important and requires additional research. In this article, we attempted to understand the impact of customer-based reputation (CBR) on customers' repatronage intentions across three hypermarkets of different sizes. We used switching inducement as a moderating variable to examine whether the relationship between $\mathrm{CBR}$ and repatronage intentions was moderated by inducements to switch. Inperson questionnaires/surveys were administered to a convenience sample to collect data from three different hypermarkets. In total, 1,099 questionnaires were collected and sorted for analysis. The results indicated that CBR had a significant positive effect on repatronage intentions in all three hypermarkets. On the other hand, a moderating effect was significant for only the smaller hypermarket, whereas there was no significantly interaction when large, multinational branded hypermarkets were considered.
\end{abstract}

Keywords: hypermarkets, customer-based reputation, repatronage intention, switching inducement, brand loyalty

\section{Introduction}

The topic of business reputation has recently attracted the attention of researchers in the domain of marketing research and strategy (Goldberg et al., 2003; Taghian et al., 2015; Walsh \& Beatty, 2007). However, according to the relevant literature, "reputation" is difficult to define, and attempts have been made to define this construct based on different features. For example, Fombrun (1996) suggested that reputation emerges from many components, including managerial quality, service and product quality, innovation, employing talented people, social responsibility, and so on. Although there is no single definition of reputation, its importance to a company is uncontestable. Interestingly, previous studies have tended to discuss the reputation of large or multinational companies by focusing on associated internal and external stakeholders (Fombrun et al., 2000; Graham \& Bansal, 2007; Taghian et al., 2015), while ignoring end-users/customers. Consequently, Walsh and Beatty (2007) based on previous research and proposed a customer-based reputation (CBR) scale with the following five dimensions, such as customer orientation, status as an employer, reliability and financial strength, product and service quality, and social and environmental responsibility. This refers to the evaluation of a firm by its customers. More specifically, it is based on how customers react to a firm's products, services, internal interactions, communication activities, and so on. For example, CBR focuses on customers' perceptions of the internal management of a company in terms of its role as an employer and examines whether employees are treated and managed well (Walsh \& Beatty, 2007). Second, it explores the perceived reliability and financial strength of a company, which relates to customers' opinions about a company's competitiveness, competence, clarity of vision, and stability in terms of profitability (Fombrun et al., 2000). Third, the dimension of product and service quality addresses a company's attempts to innovate to provide high-quality products and services (Walsh \& Beatty, 2007). Fourth, the dimension of social and environmental responsibility addresses stakeholders' perceptions of how a company acts on its environmental and social responsibilities (Maignan \& Ferrell, 2004). Additionally, they also verified the associations between CBR and various customer-outcome variables, such as customer satisfaction, trust, loyalty, word of mouth, and repatronage intentions. Generally, the CBR scale has a relatively 
strongly association with these outcome variables (see Walsh et al., 2009). In a word, the CBR scale is a multidimensional measure of a company's reputation that is rooted in a customer/end-user perspective.

Those extant studies generally focus on positive effect of reputation on customers' positive consumption behaviors. However, it is inevitable that customers may change their consumption habits at certain times. For instance, Grace and O'Cass (2001) proposed that switching inducements may lead customers to change service or product suppliers when a new supplier provides better benefits. Indeed, switching inducement is certainly important in the context of exchange for services. Therefore, it could be very interesting to explore the moderating effect of switching inducements on the relationship between CBR and consumption behaviors. At the same time, it can be argued that past research may have overlooked consumer behaviors for companies of different sizes. That means customers' consumption bahaviors to different sizes of companies yet to be articulated.

Therefore, this study demonstrated three hypermarkets of different sizes to explore the relationships between CBR and customer-outcome variables. The first hypermarket is a well-known and internationally branded hypermarket that charges an approximately $\$ 40$ USD fee for an annual membership (hereafter, Case One). The second hypermarket that also adopts the membership system is a large, very famous, multinational branded hypermarket and does not charge an annual fee (hereafter, Case Two). The last is a general local hypermarket that is smaller than both Case One and Two (hereafter, Case Three). Consequently, the first objective of this study was to examine the relationships between the CBR scale and customer-outcome variables across three hypermarkets of different sizes. The second objective was to investigate the moderating effect of switching inducement on the relationships between CBR and customer-outcome variables across the three different scales of hypermarkets.

We selected three hypermarkets of different scales for three reasons. First, the service industry may be more affected by reputation than other industries (Fombrun, 1996; Kim \& Choi, 2003). Second, Wang et al. (2003) indicated that reputation plays a critical and strategic role in service-based markets. Third, the differences between local businesses and multinational branded companies may lead to different results.

\section{Literature and Framework}

It is undoubtedly important for companies to create a positive reputation in the minds of their customers. It has been shown that business reputation is observed or judged by various customers or stakeholders. Oliver (1999) indicated that customers' subjective judgments about a company emerge from their perceptions or experiences in the course of the service process. In general, a good reputation has a positive influence on a company's sales and financial performance and attracts more customers (Brown et al., 2002; Dowling, 2004; Rose \& Thomsen, 2004). Therefore, reputation can be seen as an intangible asset that helps a company improves its competitive advantage in the market (Dowling, 2004; Hall, 1992).

Furthermore, intention is a subjective judgment about a customer will behave in the future. And, the term of repatronage intention is considered as a measurable good consumption outcome (Butcher, 2005; Soderlund \& Ohman, 2003). Hellier et al. (2003) also indicated that repatronage intention is customers' individual judgment about buying again a designed service from the same company. However, previous studies may ignore the influence of reputation on customers of different sizes of companies. Hence, this study proposed the following hypothesis

H1a: Customer-based reputation for the hypermarket of Case One has a positive effect on their customers' repatronage intention.

H1b: Customer-based reputation for the hypermarket of Case Two has a positive effect on their customers' repatronage intention.

H1c: Customer-based reputation for the hypermarket of Case Three has a positive effect on their customers' repatronage intention.

Switching inducement has been defined by Jones et al. (2000) as "the attractiveness of alternatives". In fact, the term switching inducements have been thought to influence customer behavior (Jones et al., 2000; Grace \& O'Cass, 2001). Customers will switch retailers when the loyalty programs of the original company are poor. Thus, it can be understood as a factor that may cause customers to change from one supplier to another (Grace \& O'Cass, 2001). Switching inducements may include both positive and negative factors. Keaveney (1995) proposed the following eight major negative inducements for why customers may switch suppliers: higher prices, inconvenience, core service failures, failed service encounters, responses to failed services, competition, ethical problems, and involuntary switching. On the other hand, Jones et al. (2000) also proposed several positive 
switching inducements, including cheaper prices, higher-quality services or products, more choices, and so on. Thus, both positive and negative inducements may lead customers to switch service providers. Accordingly, switching inducement can be understood to be an important factor that may influence customers' behaviors, especially in the service industry. Therefore, it is important to explore the moderating effect of switching inducement on the purchasing behaviors of customers. Since CBR is definitely a positive corporate image, this study more interested in demonstrating positive switching inducement to detect its interference effects between $\mathrm{CBR}$ and repatronage intention across three hypermarkets. Hence, the following hypotheses were proposed:

H2a: Switching inducements moderate the relationship between CBR and repatronage intentions in Case One.

$\mathrm{H} 2 \mathrm{~b}$ : Switching inducements moderate the relationship between CBR and repatronage intentions in Case Two.

H2c: Switching inducements moderate the relationship between CBR and repatronage intentions in Case Three.

\section{Research Method}

\subsection{Measures}

This research was based on the following three constructs related to the tested hypotheses: CBR, repatronage intention, and switching inducements. In total, 31 items from the CBR scale were adopted from the work of Walsh et al. (2009). Three items addressing repatronage intention were developed by Maxham and Netemeyer (2002). Moreover, this study treated positive inducement as a moderating variable. Accordingly, a modified version of the four-item, positive-switching inducement measure proposed by Jones et al. (2000) was employed. All items were assessed on a seven-point Likert-scale ranging from strongly disagree (1) to strongly agree (7). The survey also collected sociodemographic information, including age, gender, monthly income, and so on. This study also defined monthly income and average monthly consumption as controls. Monthly income was measured by the average income of consumers ( $<10,000$ to $>50,000$ NTD). Average monthly consumption was indicated by consumers' average number of monthly consumer consumption (1 to $>4$ times).

\subsection{Pilot Test}

It has been demonstrated that conducting a pilot test may be the best way to avoid potential problems with a survey (Gill \& Johnson, 2002). First, the questionnaire items were designed in English and translated into Chinese by two professional academics. They were then back-translated into English by two other university lecturers to confirm item equivalency. Second, the draft questionnaire was then distributed to three Taiwanese administrators of retail businesses and twenty Chinese-speaking customers to check for problems. Minor changes were made as a result of these respondents' suggestions. Third, 50 independent customers completed a pre-test of the revised questionnaire to confirm that respondents can complete the survey in 10 minutes.

\subsection{Data Collection and Samples}

A face-to-face questionnaire survey would be the best way to collect data because it ensures a high response rate and those respondents understand the questions. Convenience samples were selected from the three hypermarkets. Questionnaires were randomly distributed to respondents who were waiting for or just finishing checkout, outside a store's exit, or in the parking lot. In other words, all respondents had just finished shopping. The survey was conducted during three consecutive weeks. Customers were surveyed during the day and evening on both weekdays and weekends. At the end of the sampling period, 1,099 questionnaires were collected and sorted for analysis. Specifically, 364, 385, and 350 questionnaires were analyzed for Cases One, Two, and Three, respectively. The profile of respondents is shown in Table 1.

\subsection{Data Analysis}

The original CBR scale consists of 31 items, but Walsh et al. (2009) chose to use the three top-loading items for further analysis. We also decided to use a smaller set of items to examine relationships among the constructs. First, we used principal component analysis with direct oblimin (SPSS statistical software) to test five dimensions of CBR, repatronage intentions, and switching inducements for the three cases. Fortunately, as expected, all dimensions yielded one variable with eigenvalues greater than 1.0. Table 2 shows that all Kaiser-Mayer-Olkin (KMO) values were greater than 0.6 , which indicated adequate sampling (Tabachnick \& Fidell, 2007; Kaiser, 1974). The explained variance and value of Bartlett's test of sphericity reached a statistical significance of 0.05 or less (Bartlett, 1954).

Next, a factor analysis was used again to extract a new latent variable for each scale and to evaluate factor loadings. As shown in Table 3, reliability was assessed using Cronbach's alpha coefficients, which were all within the acceptable range, from 0.746 to 0.937 (Hair et al., 2010). Table 3 also shows that the composite reliability for each scale was higher than the recommended value of 0.7 , indicating adequate internal consistency. 
Moreover, all factor loadings were greater than the generally accepted level of 0.5 in the three cases. The results also reflect good convergent validity in the models (Bagozzi \& Yi, 1991). Furthermore, Table 4 shows that the discriminant validity of the three cases of constructs was supported, as the squared correlations between each pair of constructs were less than the values of the average variance extracted (AVE). We also followed the norm of using a research framework consisting of at least three (Bentler \& Chou, 1987; Kline, 2011) but not more than seven (Bollen, 1989) measures.

Table 1. Demographic profiles of respondents

\begin{tabular}{llllllll}
\hline Respondents' profile & & $\begin{array}{l}\text { Case 1 } \\
(\mathrm{n}=364)\end{array}$ & $\%$ & $\begin{array}{l}\text { Case 2 } \\
(\mathrm{n}=385)\end{array}$ & $\%$ & $\begin{array}{l}\text { Case 3 } \\
(\mathrm{n}=350)\end{array}$ & $\%$ \\
\hline Gender & Male & 151 & 41.5 & 169 & 43.9 & 167 & 47.7 \\
& Female & 213 & 58.5 & 216 & 56.1 & 183 & 52.3 \\
Age & $18-20$ & 26 & 7.1 & 29 & 7.5 & 42 & 12 \\
& $21-29$ & 83 & 22.8 & 132 & 34.3 & 142 & 40.6 \\
& $30-39$ & 83 & 22.8 & 81 & 21 & 73 & 20.9 \\
& $40-49$ & 85 & 23.4 & 70 & 18.2 & 46 & 13.1 \\
Monthly income & $>60$ & 87 & 23.9 & 73 & 19 & 47 & 13.4 \\
& $<10,000$ & 57 & 15.7 & 51 & 15.6 & 73 & 20.9 \\
& $10,001-20,000$ & 40 & 11.1 & 47 & 12.2 & 68 & 19.4 \\
& $20,001-30,000$ & 55 & 15.1 & 49 & 12.7 & 119 & 34 \\
Average monthly & $10,001-40,000$ & 90 & 24.7 & 115 & 29.9 & 64 & 18.3 \\
consumption & $>50,000$ & 122 & 33.5 & 123 & 31.9 & 26 & 7.4 \\
& 2 & 40 & 11 & 122 & 31.7 & 125 & 35.7 \\
& 3 & 132 & 36.3 & 136 & 35.3 & 86 & 24.6 \\
& $>4$ & 72 & 19.8 & 68 & 17.7 & 67 & 19.1 \\
\hline
\end{tabular}

Table 2. KMO, \% of variance and Bartlett's test of sphericity

\begin{tabular}{lllllll}
\hline & Case 1 & \multicolumn{3}{c}{ Case 2 } & Case 3 \\
\cline { 2 - 7 } & KMO & \% of vari. & KMO & \% of vari. & KMO & \% of vari. \\
\hline CO & .872 & 63.19 & .861 & 56.83 & .890 & 61.07 \\
GDE & .886 & 50.93 & .909 & 60.18 & .912 & 55.63 \\
RF & .864 & 46.74 & .895 & 54.59 & .939 & 65.72 \\
PSQ & .825 & 57.02 & .829 & 66.18 & .883 & 80.02 \\
SER & .718 & 56.05 & .799 & 65.91 & .797 & 70.42 \\
RI & .722 & 74.63 & .754 & 85.99 & .762 & 87.09 \\
SI & .723 & 55.23 & .792 & 68.89 & .731 & 63.82 \\
\hline
\end{tabular}

Note. * All results of Bartlett's test of Sphericity were passed, $\mathrm{p}<0.001$;

**CO: Customer orientation; GDE: Good employer; RF: Reliable and financially strong company; PSQ: Product and service quality; SER: Social and environmental responsibility; RI: Repatronage intention; SI: Switching inducement. 
Table 3. Measure model results across three cases

\begin{tabular}{|c|c|c|c|c|c|c|}
\hline & $\begin{array}{l}\text { Case } 1 \\
\text { Factor } \\
\text { loading } \\
\text { by PCA }\end{array}$ & $\begin{array}{l}\text { Case } 2 \\
\text { Factor } \\
\text { Loading } \\
\text { by PCA }\end{array}$ & $\begin{array}{l}\text { Case } 3 \\
\text { Factor } \\
\text { Loading } \\
\text { by PCA }\end{array}$ & $\begin{array}{l}\text { Case } 1 \\
\text { Mean/SD/SE }\end{array}$ & $\begin{array}{l}\text { Case } 2 \\
\text { Mean/SD/SE }\end{array}$ & $\begin{array}{l}\text { Case } 3 \\
\text { Mean/SD/SE }\end{array}$ \\
\hline \multicolumn{7}{|l|}{ Factor: Customer based reputation } \\
\hline Dimention 1: Customer orientation & $\alpha=.826$ & $\alpha=.833$ & $\alpha=0.849$ & $\mathrm{CR}=0.833$ & $\mathrm{CR}=0.828$ & $\mathrm{CR}=0.850$ \\
\hline 1) Has employees who treat customers courteously & .58 & .66 & .69 & $5.29 / 1.25 / .74$ & $5.12 / 1.23 / .65$ & $4.51 / 1.37 / .76$ \\
\hline 2) Treats its customers fairly & .67 & .64 & .71 & $5.38 / 1.20 / .71$ & $5.14 / 1.22 / .74$ & $4.41 / 1.48 / .79$ \\
\hline 3) Takes customer rights seriously & .73 & .68 & .66 & $5.45 / 1.28 / .76$ & $5.20 / 1.26 / .83$ & $4.43 / 1.44 / .73$ \\
\hline $\begin{array}{l}\text { 4) Seems to care about all of its customers } \\
\text { regardless of how much money they spend with } \\
\text { them }\end{array}$ & .65 & .69 & .71 & $5.22 / 1.24 / .77$ & $2.09 / 1.30 / .73$ & $4.31 / 1.53 / .78$ \\
\hline Dimention 2: Good employer & $\alpha=.802$ & $\alpha=.849$ & $\alpha=0.834$ & $\mathrm{CR}=0.851$ & $\mathrm{CR}=0.803$ & $\mathrm{CR}=0.836$ \\
\hline 1) Looks like a good company to work for & .60 & .56 & .56 & $5.40 / 1.19 / .67$ & $4.88 / 1.34 / .71$ & $4.93 / 1.30 / .66$ \\
\hline 2) Seems to have excellent leadership & .54 & .70 & .56 & $5.24 / 1.17 / .81$ & $4.81 / 1.27 / .65$ & $4.22 / 1.48 / .66$ \\
\hline $\begin{array}{l}\text { 3) Has management who seems to pay attention to } \\
\text { the needs of its employees }\end{array}$ & .54 & .69 & .66 & $5.15 / 1.16 / .80$ & $4.73 / 1.22 / .65$ & $4.27 / 1.47 / .77$ \\
\hline 4) Seems to have good employees & .59 & .59 & .56 & $5.49 / 1.60 / .68$ & $5.06 / 1.24 / .70$ & $4.69 / 1.39 / .67$ \\
\hline $\begin{array}{l}\text { 5) Seems to maintain high standards in the way that } \\
\text { it treats people }\end{array}$ & .53 & .60 & .67 & $5.39 / 1.12 / .70$ & $4.81 / 1.27 / .65$ & $4.53 / 1.40 / .78$ \\
\hline $\begin{array}{l}\text { Dimention 3: Reliable and financially strong } \\
\text { company }\end{array}$ & $\alpha=.816$ & $\alpha=.836$ & $\alpha=0.838$ & $\mathrm{CR}=0.829$ & $\mathrm{CR}=0.829$ & $\mathrm{CR}=0.842$ \\
\hline $\begin{array}{l}\text { 1) Seems to recognise and take advantage of market } \\
\text { opportunities }\end{array}$ & t .80 & .79 & .78 & $5.66 / 1.07 / .86$ & $4.59 / 1.16 / .86$ & $4.28 / 1.45 / .84$ \\
\hline $\begin{array}{l}\text { 2) Looks like it has strong prospects for future } \\
\text { growth }\end{array}$ & .80 & .74 & .71 & $5.41 / 1.20 / .87$ & $4.54 / 1.13 / .87$ & $4.35 / 1.49 / .73$ \\
\hline 3) Looks like it would be a good investment & .62 & .74 & .78 & $5.46 / 1.21 / .62$ & $4.43 / 1.27 / .62$ & $4.27 / 1.45 / .83$ \\
\hline Dimention 4: Product and service quality & $\alpha=.810$ & $\alpha=.871$ & $\alpha=0.937$ & $\mathrm{CR}=0.873$ & $\mathrm{CR}=0.812$ & $\mathrm{CR}=0.938$ \\
\hline 1) Offers high quality products and services & .59 & .70 & .76 & $5.75 / 1.10 / .78$ & $5.23 / 1.32 / .71$ & $4.81 / 1.31 / .82$ \\
\hline 2) Is a strong, reliable company & .57 & .61 & .80 & $5.59 / 1.10 / .71$ & $5.02 / 1.19 / .68$ & $4.63 / 1.34 / .85$ \\
\hline 3) Stands behind the services that it offers & .61 & .71 & .82 & $5.74 / 1.12 / .81$ & $5.08 / 1.19 / .72$ & $4.74 / 1.39 / .88$ \\
\hline 4) Develops innovative services & .52 & .69 & .81 & $5.43 / 1.21 / .79$ & $4.78 / 1.27 / .63$ & $4.45 / 1.47 / .87$ \\
\hline $\begin{array}{l}\text { 5) Offers services that are a good value for the } \\
\text { money }\end{array}$ & .56 & .60 & .81 & $5.67 / 1.23 / .71$ & $4.89 / 1.36 / .71$ & $4.57 / 1.46 / .89$ \\
\hline $\begin{array}{l}\text { Dimension 5: Social and environmental } \\
\text { responsibility }\end{array}$ & $\alpha=.750$ & $\alpha=.790$ & $\alpha=0.815$ & $\mathrm{CR}=0.794$ & $\mathrm{CR}=0.752$ & $\mathrm{CR}=0.819$ \\
\hline 1) Seems to make an effort to create new jobs & .63 & .65 & .64 & $5.78 / 1.19 / .67$ & $5.60 / 1.21 / .66$ & $5.14 / 1.18 / .65$ \\
\hline 2) Seems to be environmentally responsible & .69 & .75 & .78 & $5.02 / 1.27 / .83$ & $4.68 / 1.15 / .75$ & $4.55 / 1.32 / .84$ \\
\hline 3) Appears to support good causes & .68 & .71 & .77 & $5.29 / 1.27 / .75$ & $5.10 / 1.21 / .72$ & $4.85 / 1.31 / .83$ \\
\hline Factor: Repatronage intentions & $\alpha=.829$ & $\alpha=.918$ & $\alpha=0.925$ & $\mathrm{CR}=0.919$ & $\mathrm{CR}=0.830$ & $\mathrm{CR}=0.926$ \\
\hline $\begin{array}{l}\text { 1) I intend to remain a customer of this } \\
\text { hypermarkets }\end{array}$ & .73 & .87 & .86 & $5.75 / 1.14 / .90$ & $5.17 / 1.35 / .76$ & $5.17 / 1.27 / .88$ \\
\hline $\begin{array}{l}\text { 2) I plan to go shopping at this hypermarket in the } \\
\text { future }\end{array}$ & .74 & .88 & .89 & $5.78 / 1.12 / .92$ & $5.04 / 1.32 / .78$ & $4.98 / 1.21 / .92$ \\
\hline $\begin{array}{l}\text { 3) I would like to go shopping at this hypermarket } \\
\text { in the future }\end{array}$ & .77 & .83 & .87 & $5.74 / 1.07 / .85$ & $5.03 / 1.34 / .82$ & $5.06 / 1.19 / .90$ \\
\hline Factor: Switching inducement & $\alpha=.746$ & $\alpha=.879$ & $\alpha=0.901$ & $\begin{array}{l}\mathrm{CR}=0.880 \\
\mathrm{AVE}=0.710\end{array}$ & $\begin{array}{l}\mathrm{CR}=0.757 \\
\mathrm{AVE}=0.514\end{array}$ & $\begin{array}{l}\mathrm{CR}=0.902 \\
\mathrm{AVE}=0.755\end{array}$ \\
\hline $\begin{array}{l}\text { 1) If I needed to change a hypermarket, there are } \\
\text { other good hypermarkets to choose from }\end{array}$ & .74 & .81 & .87 & $4.96 / 1.28 / .85$ & $5.67 / 1.27 / .84$ & $5.10 / 1.38 / .91$ \\
\hline $\begin{array}{l}\text { 2) I would probably be happy with the products and } \\
\text { services of another hypermarket }\end{array}$ & .67 & .83 & .84 & $4.77 / 1.33 / .88$ & $5.42 / 1.22 / .70$ & $5.04 / 1.35 / .88$ \\
\hline $\begin{array}{l}\text { 3) Compared to this hypermarket, there are other } \\
\text { hypermarkets with which I would probably be } \\
\text { equally of more satisfied. }\end{array}$ & .59 & .77 & .80 & $4.25 / 1.45 / .79$ & $5.24 / 1.26 / .59$ & $4.98 / 1.27 / .81$ \\
\hline
\end{tabular}


Table 4. Scale analysis properties

\begin{tabular}{|c|c|c|c|c|c|c|c|c|c|c|c|c|c|c|c|c|c|c|}
\hline & \multicolumn{6}{|c|}{ Case 1} & \multicolumn{6}{|c|}{ Case 2} & \multicolumn{6}{|c|}{ Case 3} \\
\hline & 1 & 2 & 3 & 4 & 5 & 6 & 1 & 2 & 3 & 4 & 5 & 6 & 1 & 2 & 3 & 4 & 5 & 6 \\
\hline $\mathrm{CO}$ & $(.556$ & & & & & & $(.548$ & & & & & & $(.58$ & & & & & \\
\hline GDE & .49 & $(.535)$ & & & & & .60 & $(.449$ & & & & & .52 & $(.506$ & & & & \\
\hline RF & .34 & .51 & $(.623)$ & & & & .38 & .38 & (.623) & & & & .50 & .46 & $(.638)$ & & & \\
\hline PSQ & .47 & .61 & .56 & $(.579)$ & & & .59 & .62 & .41 & $(.460)$ & & & .49 & .53 & .66 & $(.750)$ & & \\
\hline SER & .41 & .51 & .34 & .55 & $(.564)$ & & .56 & .63 & .32 & .67 & $(.503)$ & & .45 & .53 & .61 & .75 & $(.605)$ & \\
\hline RI & .44 & .56 & .53 & .67 & .56 & $(.791)$ & .36 & .39 & .26 & .45 & .51 & $(.620)$ & .43 & .60 & .54 & .62 & .71 & $(.807)$ \\
\hline
\end{tabular}

Note. All correlations are significant at the 0.01 level (2-tailed); Numbers in parentheses are the AVE values.

A confirmatory factor analysis (CFA) (Anderson \& Gerbing, 1988) was used to test the measurement model. The CFA model showed the relationships among the constructs on the five dimensions of the CBR scale. Additionally, our model of repatronage intentions fit the data well in all three cases. In Case $1, \mathrm{X}^{2}=466.17(\mathrm{df}=224)$, the root means square error of approximation (RMSEA) $=0.053$, goodness-of-fit index $(\mathrm{GFI})=0.897$, the adjusted goodness-of-fit index $(\mathrm{AGFI})=0.873$, and the comparative fit index $(\mathrm{CFI})=0.951$. In Case $2, \mathrm{X}^{2}=384.56(\mathrm{df}=$ 224), the RMSEA $=0.044$, the GFI $=0.915$, the $\mathrm{AGFI}=0.896$, and the $\mathrm{CFI}=0.956$. In Case $3, \mathrm{X}^{2}=651.79(\mathrm{df}=$ 224), the RMSEA $=0.074$, the GFI $=0.846$, the $\mathrm{AGFI}=0.810$, and the $\mathrm{CFI}=0.925$. All chi-square values were significant $(\mathrm{p}<0.001)$, indicating that the five dimensions of CBR and repatronage intentions are mutually distinct constructs and that they demonstrated acceptable goodness of fit with regard to all three cases.

\section{Hypothesis Testing}

Of the various multivariate techniques available for this research, this study decided to use structural equation models to examine structural relationships among sets of variables and assigned several variables to a single independent or dependent variable (Hair et al., 2010). Specifically, SME with Mplus was used to test the proposed relationships embedded in the research framework. Mplus (Muthén \& Muthén, 2007) was used because it is the only program that performs both normal-theory and bootstrap methods to estimate indirect effects (Preacher \& Hayes, 2008). It is also available in software form to perform contrasts of indirect effects (Cheung, 2007).

The data were analyzed using Mplus, and the results are shown in Table 5. The results show that CBR had a significantly positive association with repatronage intentions in the three hypermarkets: $\beta=1.436,0.954$ and 1.241 and $\mathrm{t}$-value $=7.827,7.267$ and 8.544, respectively. The results supported H1a, H1b and H1c. The results also indicated that $\mathrm{H} 2 \mathrm{c}$ was supported and $\mathrm{H} 2 \mathrm{a}$ and $\mathrm{H} 2 \mathrm{~b}$ were not supported where $\beta=-0.072,-0.017$, and -0.123 and t-value $=-0.298,1.032$, and -3.012 , respectively. Thus, the moderating effect of switching inducement on the relationship between CBR and repatronage intentions occurs only in small and local hypermarkets. Although the results suggest the moderating effect on Case 1 and 2 were not significant, a negative effect had been shown which indicating the more positive switching inducement experienced, the less the consumer repatronage intention.

Table 5. Test of hypothesis for the for cases

\begin{tabular}{|c|c|c|c|c|c|c|}
\hline \multirow{3}{*}{ Independent Variables } & \multicolumn{6}{|c|}{ Dependent Variable: Repatronage intention } \\
\hline & \multicolumn{2}{|l|}{ Case One } & \multicolumn{2}{|l|}{ Case Two } & \multicolumn{2}{|l|}{ Case Three } \\
\hline & $\beta$ & $\mathrm{t}$-value & $\beta$ & $\mathrm{t}$-value & $\beta$ & $\mathrm{t}$-value \\
\hline CBR & $1.436 * * *$ & 7.827 & $0.954 * * *$ & 7.267 & $1.241 * * *$ & 8.544 \\
\hline SI & -0.018 & -0.441 & 0.058 & 1.142 & $0.145^{* * *}$ & 4.036 \\
\hline SI x CBR & -0.072 & -1.032 & -0.017 & -0.298 & $-0.123 *$ & -3.012 \\
\hline \multicolumn{7}{|l|}{ Control Variables } \\
\hline Monthly income & $0.063 *$ & 2.453 & -0.02 & -0.563 & 0.038 & 1.143 \\
\hline Average monthly consumption & $0.061^{*}$ & 2.059 & $0.118^{*}$ & 2.466 & $0.163 * * *$ & 4.276 \\
\hline Sample size & 364 & & 385 & & 350 & \\
\hline
\end{tabular}

\subsection{The Effects of Controls}

Monthly income has insignificant effects on repatronage intention in Cases Two and Three. It appears that higher monthly income customers are less willing to consume in the same place than lower monthly income customers. 
On the other hand, for Case One, monthly income is positively and significantly related to repatronage intention, suggesting that the consumers of Case One with higher incomes are more willing to spend at the hypermarket. In addition, average monthly consumption is also positively and strongly related to repatronage intention across three cases as an indicator of the more consumers consume at a place, the higher the willingness to repurchase.

\section{Conclusion and Implication}

Business reputation is a very important topic for both customers and companies. However, to our knowledge, this article is the first to investigate the influence of reputation on the behavior of end-users/customers across three hypermarkets of different sizes. At the same time, this is the first study to explore the moderating effect of switching inducement on the relationship between reputation and repatronage intentions. The result indicates that CBR directly affects customers' repatronage intentions. This finding is consistent with many extant theoretical assumptions regarding business reputation (e.g., Davies et al., 2002; Goldberg et al., 2003; Walsh \& Beatty, 2006; 2009). More specifically, business reputation has been shown to greatly enhance the attitudes of customers toward companies, which subsequently affects their final behavior. Moreover, the results not only confirm that business reputation is positively associated with customers' intentions but also verifies that reputation affects the purchasing behaviors of customers regardless of company size. Therefore, customer-based judgments or feelings related to the five dimensions of CBR have an additive effect on how customers perceive and react to a company.

On the other hand, the influence of switching inducement on the examined relationships may be based on the size of the hypermarket involved. This moderating effect was significant for only the smaller hypermarket, whereas there was no significantly interaction when large, multinational branded hypermarkets were considered. The plausible explanation is that the smaller hypermarket was more strongly influenced by moderating variables than were the famous and large ones. Consequently, this study makes an important contribution to the literature by examining the effect of business reputation from an end-user/customer perspective on customers' repatronage intentions, as well as by investigating the influence of the switching inducements that putatively affect this behavior.

\subsection{Managerial Implications}

First, this study suggests that the results of the study can be extended to customer commitment. Indeed, previous studies have proposed that customer commitment should include affective, continuance, and normative dimensions (Bansal et al., 2004; Fullerton, 2005; Gruen et al., 2000). Affective commitment can be defined as a form of "psychological attachment" which is widely discussed. For example, Bansal et al. (2004) used it as "desire-based attachment", while Gundlach et al. (1995) defined psychological attachment to include the behavioral intention of remaining in a relationship. Moreover, continuance commitment draws attention on switching costs, or the difficulty in replacing a business partner (Harrison-Walker, 2001).

According to the results that hypermarkets charge annual fees and branded hypermarkets were not easily influenced by switching inducements. This could be because consumers who agree to pay an annual fee express an affective commitment to the brand, and a hypermarket with a membership fee system can easily establish a continuance commitment to consumers. These commitments indicate a member-owned store whose consumers are less willing to change their consumption place. On the other hand, it can also be considered as the conversion is not easy because of high annual fees to form a locked relationship, a forced continuance commitment to persistent. Evanschitzky et al. (2006) demonstrate that continuance commitment is a less enduring source of loyalty compared with affective commitment. Consequently, this study recommends both Case One and Two should establish affective commitment with customers to attract them returning to the shops.

Second, in a highly challenging business environment, the success of a company sometimes depends on its ability to create a trusted brand and subsequently establish brand loyalty (Thompson et al., 2014). One of the advantages of brand loyalty is that it helps to improve sales and increase the probability of a company (Chaudhuri \& Holbrook, 2001). This benefit has been shown to develop considerably more rapidly in the presence of brand loyalty versus in companies without brand loyalty (Ren et al., 2016). Brand loyalty can help firms remain competitive (Brexendorf et al., 2010) and encourage customers to continue purchasing a preferred product, revisit a place in the future, and avoid switching behavior (Oliver, 1999). Accordingly, this study also suggests that managers should try harder to establish brand image and long-lasting client relationships. When a company has a stronger relationship with its customers and these customers form a more enduring impression of a company (Case One and Case Two), there are fewer opportunities for the customer to be influenced by other external factors.

Third, as the characteristics of small and local businesses (e.g. financial constraints, owner management, limited resources) (Stokes \& Wilson, 2002) make it difficult to promote the companies or their services to customers. 
The switching cost of moving between the loyalty programs offered by smaller retailers is relatively low compared with that associated with moving between the loyalty programs of larger retailers. In Case Three, the small hypermarket, is easy conversion and to be replaced by other hypermarkets. Switching intention may weaken the positive relationship between the brand image and remarketing intention. This indicated that the smaller retailer did not form a commitment in customers' mind. Although it is very difficult to establish a loyalty program for a small or local business, managers should nonetheless commit to strengthening the effectiveness of these programs with their customers. This study therefore suggests that rewarding customers by offering a membership card which similar to Case Two, or even a coupon, may be a good method for establishing long-term relationships. In fact, such a membership card program can be considered strategic tools for developing personalized relationships with customers and strengthening customer loyalty. This kind of business behavior could enhance customers' affective commitment and attachment to the organization and thereby entail higher switching costs. Those customers who become members of membership programmes likely identify more strongly with the company, which is especially beneficial in industries in which consumers purchase frequently (Bhattacharya \& Sen, 2003). Overall, our findings contribute to managerial practice by providing new insights for remain remaining or attracting new customers for different kinds of hypermarkets.

Fourth, according to the results of effect of control variable, it can be indicated that the more often consumers consume at the same hypermarket; the less likely they switch to a place of consumption. This suggests that stores should try to establish customer commitment to them.

\subsection{Theoretical and Method Implication}

This study is an inaugural attempt to explore the moderating effect of positive switching inducement on the relationship between business reputation and behavior of end-users/customers across three hypermarkets of different sizes. Further research may concentrate more on interdependencies among reputation characteristics, and how these affect customers' behaviors. The findings of this study also confirm that the appeal of moderating effect may be only occurred on the smaller hypermarket. The findings furthermore suggest that customer-based reputation is conductive to attract more customers, thereby unfolding the different strategies to different prospective customers.

\section{Limitation and Further Research}

This study also has several limitations. First, we used convenience samples in three hypermarkets to collect data. Thus, we do not know the intent of our participants, for example, we do not know if customers were shopping because of a promotion. The purpose of a customer's shopping trip might be a critical issue and should be considered in further research. Second, further research is required to investigate other moderating variables that may affect customer relationships and influence purchasing behaviors (e.g., convenience). Additionally, it would be interesting to examine other service providers. For example, restaurants could be a very suitable target sample for CBR research because their products and services are directly experienced by customers. Indeed, reputation is a very interesting topic, and different industries may have different definitions of reputation. Thus, additional research on reputation is required. Fourth, this study also offers a critical insight for studying business reputation and customers' repatronge intention. For example, according to Table 3, the importance of the same CBR construct may be very important or not very important for customers of different hypermarkets. Hence, we suggest that further research on reputation be conducted on small businesses in addition to on large or multinational companies. The characteristics of businesses differ as a function of their size, and such differences may entail the use of different marketing tools. The effects of such differences should be considered. Finally, more research also should address the effects of business reputations on affective commitment and customer loyalty.

\section{References}

Anderson, J. C., \& Gerbing, D. W. (1988). Structural equation modeling in practice: A review and recommended two-step approach. Psychological Bulletin, 103(3), 411-423. https://doi.org/10.1037/0033-2909.103.3.411

Bagozzi, R. P., \& Yi, Y. (1991). Multitrait-Multimethod matrices in consumer research. Journal of Consumer Research, 17(4), 426-439. https://doi.org/10.1086/208568

Bansal, H. S., Irving, P. G., \& Taylor, S. F. (2004). A Three - component model of customer commitment to service providers. Journal of the Academy of Marketing Science, 32(3), 234-250. https://doi.org/10.1177/0092070304263332

Bartlett, M. S. (1954). A note on the multiplying factors for various chi square approximations. Journal of the Royal Statistical Society, 16(2), 296-298. https://doi.org/10.1111/j.2517-6161.1954.tb00174.x 
Bentler, P. M., \& Chou, C. P. (1987). Practical issues in structural modeling. Sociological Methods and Research, 16(1), 78-87. https://doi.org/10.1177/0049124187016001004

Bhattacharya, C B., \& Sen, S. (2003). Consumer-company identification: a framework for understanding consumers' relationships with companies. Journal of Marketing, 67(2), 76-88. https://doi.org/10.1509/jmkg.67.2.76.18609

Bollen, K. A. (1989). Structural Equations with Latent Variable. New York: Wiley. https://doi.org/10.1002/9781118619179

Brexendorf, T. O., Mühlmeier, S., Tomczak, T., \& Eisend, M. (2010). The impact of sales encounters on brand loyalty. Journal of Business Research, 63(11), 1148-1155. https://doi.org/10.1016/j.jbusres.2009.10.011

Brown, T. J., Mowen, J. C., Donavan, D. T., \& Licata, J. W. (2002). The customer orientation of service workers: Personality trait effects on self-and supervisor performance ratings. Journal of Marketing Research, 39(1), 110-119. https://doi.org/10.1509/jmkr.39.1.110.18928

Butcher, K. (2005). Differential impact of social influence in the hospitality encounter. International Journal of Contemporary Hospitality Management, 17(2), 125-135. https://doi.org/10.1108/09596110510582323

Chaudhuri, A., \& Holbrook, M. B. (2001). The chain of effects from brand trust and brand affect to brand performance: The role of brand loyalty. Journal of Marketing, 65(2), 81-93. https://doi.org/10.1509/jmkg.65.2.81.18255

Cheung, M. W. L. (2007). Comparison of approaches to constructing confidence intervals for mediating effects using structural equation models. Structural Equation Modeling: A Multidisciplinary Journal, 14(2), 227-246. https://doi.org/10.1080/10705510709336745

Chintagunta, P. K. (1998). Inertia and variety seeking in a model of brand-purchase timing. Marketing Science, 17(3), 253-270. https://doi.org/10.1287/mksc.17.3.253

Davies, G., Chun, R., da Silva R. V., \& Roper, S. (2002). Corporate Reputation and Competitiveness. London: Routledge.

Dowling, G. R. (2004). Corporate reputations: Should you compete on yours? California Management Review, 46(3), 19-36. https://doi.org/10.2307/41166219

Evanschitzky, H., Iyer, G. R., Plassmann, H., Niessing, J., \& Meffert, H. (2006). The relative strength of affective commitment in securing loyalty in service relationships. Journal of Business Research, 59(12), 1207-1213. https://doi.org/10.1016/j.jbusres.2006.08.005

Fombrun, C. J. (1996). Reputation, Realizing Value from Corporate Image. Boston, MA: Harvard Business School Press.

Fombrun, C. J., Gardberg, N. A., \& Sever, J. M. (2000). The reputation quotient: A multi-stakeholder measure of corporate reputation. The Journal of Brand Management, 7(4), 241-255. https://doi.org/10.1057/bm.2000.10

Fombrun, C. J., \& Shanley, M. (1990). What's in a name? Reputation building and corporate strategy. Academy of Management Journal, 33(1), 233-258. https://doi.org/10.5465/256324

Fullerton, G. (2005). The impact of brand commitment on loyalty to retail service brands. Canadian Journal of Administrative Sciences, 22(2), 97-110. https://doi.org/10.1111/j.1936-4490.2005.tb00712.x

Gill, J., \& Johnson, P. (2002). Research Methods for Managers. London: SAGE Publication.

Goldberg, A. I., Cohen, G., \& Fiegenbaum, A. (2003). Reputation building: Small business strategies for successful venture development. Journal of Small Business Management, 41(2), $168-186$. https://doi.org/10.1111/1540-627X.00074

Grace, D., \& O'Cass, A. (2001). Attributions of service switching: A study of consumers' and providers' perceptions of child-care service delivery. The Journal of Services Marketing, 15(4), 300-321. https://doi.org/10.1108/EUM0000000005508

Graham, M. E., \& Bansal, P. (2007). Consumers' willingness to pay for corporate reputation: The context of airline companies. Corporate Reputation Review, 10(3), 189 -200. https://doi.org/10.1057/palgrave.crr.1550052

Gruen, T. W., Summers, J. O., \& Acito, F. (2000). Relationship marketing activities, commitment, and membership behaviors in professional associations. Journal of Marketing, 64(3), 34-49. 
https://doi.org/10.1509/jmkg.64.3.34.18030

Gundlach, G. T., Achrol, R. S., \& Mentzer, J. T. (1995). The structure of commitment in Exchange. Journal of Marketing, 59(1), 78-92. https://doi.org/10.1177/002224299505900107

Hair, J. F., Black, W. C., Babin, B. J., \& Anderson, R. E. (2010). Multivariate data analysis: A global perspective. London: Pearson.

Hall, R. (1992). The strategic analysis of intangible resources. Strategic Management Journal, 13(2), $135-144$. https://doi.org/10.1002/smj.4250130205

Harrison-Walker, J. L. (2001). The measurement of word-of-mouth communication and an investigation of service quality and customer commitment as potential antecedents. Journal of Service Research, 4(1), 60-75. https://doi.org/10.1177/109467050141006

Hellier, P. K., Geursen, G. M., Carr, R. A., \& Rickard, J. A. (2003). Customer repurchase intention: A general structural equation model. European Journal of Marketing, 37(11/12), $1762-1800$. https://doi.org/10.1108/03090560310495456

Jones, M. A., Mothersbaugh, D. L., \& Beatty, S. E. (2000). Switching barriers and repurchase intentions in service. Journal of Retailing, 76(2), 259-274. https://doi.org/10.1016/S0022-4359(00)00024-5

Kaiser, H. F. (1974). An index of factorial simplicity. Psychometrika, 39(1), 31-36. https://doi.org/10.1007/BF02291575

Keaveney, S. M. (1995). Customer switching behavior in service industries: An exploratory study. Journal of Marketing, 59(2), 71-82. https://doi.org/10.1177/002224299505900206

Kim, J. B., \& Choi, C. J. (2003). Reputation and product tampering in service industries. Service Industries Journal, 23(4), 3-11. https://doi.org/10.1080/02642060412331300972

Kline. R. B. (2011). Principles and Practice of Structural Equation Modeling. New York: Guilford.

Maignan, I., \& Ferrell, O. C. (2004). Corporate Social Responsibility and Marketing: An Integrative Framework. Journal of the Academy of Marketing Science, 32(1), 3-19. https://doi.org/10.1177/0092070303258971

Muthén, L. K., \& Muthén, B. O. (2007). Mplus user’s guide. Los Angeles: Muthén and Muthén.

Oliver, R. L. (1999). Whence consumer loyalty. Journal of Marketing, 63(4), 33-44. https://doi.org/10.1177/00222429990634s105

Preacher, K. J., \& Hayes, A. F. (2008). Asymptotic and resampling strategies for assessing and comparing indirect effects in multiple mediator models. Behavior Research Methods, 40(3), 879-891. https://doi.org/10.3758/BRM.40.3.879

Ren, L., Qiu, H., Wang, P., \& Lin, P. M. C. (2016). Exploring customer experience with budget hotels: Dimensionality and satisfaction. International Journal of Hospitality Management, 52(1), $13-23$. https://doi.org/10.1016/j.ijhm.2015.09.009

Rose, C., \& Thomsen, S. (2004). The impact of corporate reputation on performance: Some Danish evidence. European Management Journal, 22(2), 201-210. https://doi.org/10.1016/j.emj.2004.01.012

Soderlund, M., \& Ohman, N. (2003). Behavioural intentions in satisfaction research revisited. Journal of Consumer Satisfaction, Dissatisfaction and Complaining Behaviour, 16, 53-66.

Stokes, D., \& Wilson, N. (2002). Small Business Management and Entrepreneurship. London: South-Western Cengage Learning.

Tabachnick, B. G., \& Fidell, L. S. (2007). Using Multivariate Statistics. Boston: Pearson Education.

Taghian, M., D’Souza, C., \& Polonsky, M. J. (2015). A stakeholder approach to corporate social responsibility, reputation and business performance. Social Responsibility Journal, 11(2), 340-363. https://doi.org/10.1108/SRJ-06-2012-0068

Thompson, F. M., Newman, A., \& Liu, M. (2014). The moderating effect of individual level collectivist values on brand loyalty. Journal of Business Research, 67(11), 2437-2446. https://doi.org/10.1016/j.jbusres.2014.02.011

Walsh, G., \& Beatty, S. E. (2007). Customer-based corporate reputation of a service firm: Scale development and validation. Journal of the Academy of Marketing Science, 35(1), $127-143$. https://doi.org/10.1007/s11747-007-0015-7 
Walsh, G., Beatty, S. E., \& Shiu, E. M. K. (2009). The customer-based corporate reputation scale: Replication and short form. Journal of Business Research, 62(10), 924-930. https://doi.org/10.1016/j.jbusres.2007.11.018

Walsh, G., Dinnie, K., \& Wiedmann, K.-P. (2006). How do corporate reputation and customer satisfaction impact customer defection? A study of private energy customers in Germany. Journal of Services Marketing, 20(6), 412-420. https://doi.org/10.1108/08876040610691301

Wang, Y., Lo, H. P., \& Hui, Y. V. (2003). The antecedents of service quality and product quality and their influence on bank reputation: Evidence from the banking industry in China. Managing Service Quality: An International Journal, 13(1), 72-83. https://doi.org/10.1108/09604520310456726

\section{Copyrights}

Copyright for this article is retained by the author, with first publication rights granted to the journal.

This is an open-access article distributed under the terms and conditions of the Creative Commons Attribution license (http://creativecommons.org/licenses/by/4.0/). 